\title{
Rethinking the intercultural communicative competence evaluation in higher education
}

\author{
Tatyana Nikolaevna Yefremtseva ${ }^{1}$, Ryskul Ekinovna Musagulova ${ }^{2,3}$, Olga Vladimirovna \\ Takanova $^{4}$, Aleksei Analolievich Zaitsev ${ }^{4}$, and Natalya Anatolievna Sergeeva ${ }^{4}$ \\ ${ }^{1}$ Russian International Academy for Tourism, Faculty of Tourism Management, Khimki, Russia \\ ${ }^{2}$ Financial University under the Government of the Russian Federation, Department of Foreign \\ Languages and Intercultural Communication, Moscow, Russia \\ ${ }^{3}$ University of Transport, Navigation Department, Moscow, Russia \\ ${ }^{4}$ Russian State Agrarian University - Moscow Timiryazev Agricultural Academy, Department of \\ Russian and Foreign Languages, Moscow, Russia
}

\begin{abstract}
The information and digitalization age, the current phase of globalization are changing the way we think about cultures and communities and, as language teachers and cultural trainers, potentially about what and how we teach. Intercultural communicative competence is as needed as ever in today's world of geo-economic changes, migration, and rising ethnic and national tensions. To prepare future professionals, there have been different efforts in education including the intercultural and communicative components. The essential contradictions in the language and professional training of students, associated with insufficient attention to the issues of interaction of cultures in the content of university curricula, are highlighted. The Map of Intercultural Communicative Competence Formation in Higher Education is developed considering the contents of bachelor and master programmes for Russian and foreign students. The main emphasis is paid to the separate subjects in intercultural communication study. New approaches to the evaluation of the intercultural communicative competence of students in a multicultural environment are proposed, among which a special focus is placed on the need to organize international projects and conduct events in narrow professional fields. Some examples of tasks to assess the competence in cross-cultural communication show practical application and significance of those disciplines for university students in their future career.

Keywords: intercultural communicative competence, cultural types
\end{abstract}

\section{Introduction}

Modern transfer of the world civilization development from monocentric to polycentric model of the world affects all fields of human activities - economic, political, social, cultural, etc. Globalization, internationalization and the restrictions of pandemic situation of the last months brought us to the idea of looking differently on the issues of intercultural

*Corresponding author: efremtseva@rmat.ru 
interaction in the world and the cross-cultural challenges our students face while getting higher education.

Preparing students for life in a multicultural world means giving them instruments for an intercultural dialogue and fully engagement in the process.

At universities students are culturally rich, including international and local students; therefore, they are locations representing a micro-reality of broader community within which intercultural interactions and learning opportunities occur. "Both local and foreign students would benefit from gaining a more nuanced understanding of the cultural and linguistic diversity available in the community. Collaborative exchanges among all diverse groups in a university could provide an additional or even an alternative intercultural experience that is available to all students" [1].

However, we are seeing serious contradictions today between:

- need to build intercultural communicative competence in students in many federal state educational standards and lack of special disciplines on cross-cultural communication in most curricula;

- including intercultural communication in the course of foreign languages and insufficient amount of time to build this competence;

- need for intercultural communication of students and low interest of university administration in organizing intercultural communication practice.

This paper aims to review and summarize the contents of intercultural communication as a subject to develop a guiding map and to create the tools of intercultural communicative competence evaluation considering the best experience accumulated in some universities of Russia.

\section{Methods}

In our work we used the methods of theoretical research: abstraction and concretization of intercultural communicative competence in higher education [1-5]; theoretical analysis of methods, criteria and quality indicators as well as modeling the cultural picture of the world [6-11]; the study of specialized literature on the problems of assessing the intercultural communicative competence [12-18], as well as empirical research methods based on the experience of assessing the intercultural communicative competence formation and evaluation in some universities abroad and in Russia [19, 20]; a method of expert evaluations of the intercultural communicative competence [3, 4, 12].

The research was conducted in the constructivist tradition - seeking to co-create knowledge between researchers and stakeholders regarding their perceptions and findings towards their professional experiences.

Deardorff sees cross-cultural competence formation starting with "an attitude of respect, openness, and curiosity, self-awareness and the skills to listen, observe, evaluate, analyze, and relate to others" [4].

As a complex phenomenon, intercultural communicative competence covers diverse ingredients we should focus in assessment. The characteristics of intercultural communicative competence, in Byram's opinion, include: flexibility, humour, "patience, openness, interest, curiosity, empathy and tolerance for ambiguity" [12].

In order, the intercultural communication to be successful the teacher's role and tasks are extended considerably. Consequently, when assessing intercultural communicative competence, one cannot be concerned with traditional grades, but rather with creative techniques to determine progress towards the development of competencies while using quantitative and qualitative approaches. 


\section{$3 \quad$ Results}

Before the evaluation of students' competence, we developed a Map of intercultural communicative competence formation for universities.

We are sure about a stringent system in the content of intercultural studies depending on the level of university programme.

We see the following logics: Culture - Native Country - Cultural Types - Cultural Dimensions - Country Cultural Profile - Personal Cultural Profile.

It means that every time we should start with the proper understanding of the notion Culture. The Cultural Iceberg is of great assistance here. The next step is studying and understanding the Native country of learners (Russia, in our case). The depth of exploration depends on the programme and the level of the group.

The theory of Cultural Types and Models could be better studied as follows: Lewis Model - Hofstede's Cultural Dimensions - Barry Tomalin's Country and Personal Cultural Profiles. In low groups of Bachelors, better start with general understanding of Types of Cultures (Fact cultures - People cultures - Trust cultures) [21].

The Map of Intercultural Communicative Competence Formation in Higher Education in table 1 shows three levels of programmes (Russian Bachelor students, Russian and foreign Master students) and the succession of themes to study with the level depth.

Table 1. Map of intercultural communicative competence formation in higher education [19].

\begin{tabular}{|c|c|c|c|}
\hline $\begin{array}{c}\text { Barry } \\
\text { Tomalin's } \\
\text { Country and } \\
\text { Personal } \\
\text { Cultural } \\
\text { Profiles } \\
\end{array}$ & $\begin{array}{c}\text { Russia Cultural } \\
\text { Profile }\end{array}$ & $\begin{array}{c}\text { Comparison of } \\
\text { Russia Cultural } \\
\text { Profile with the } \\
\text { profile of any } \\
\text { country (student's } \\
\text { choice) } \\
\end{array}$ & $\begin{array}{c}\text { Comparative } \\
\text { analysis of Country } \\
\text { Cultural Profiles } \\
\text { (e.g. Russia - Italy, } \\
\text { Russia - France) }\end{array}$ \\
\hline & \multicolumn{3}{|c|}{ Personal Cultural Profiles } \\
\hline $\begin{array}{l}\text { Geert } \\
\text { Hofstede's } \\
\text { Cultural } \\
\text { Dimensions }\end{array}$ & no & $\begin{array}{l}\text { Comparison of } \\
\text { Russia with any } \\
\text { country by students' } \\
\text { interests } \\
\text { in Hofstede's } \\
\text { Cultural Dimensions }\end{array}$ & $\begin{array}{l}\text { Comparison of } e . g \text {. } \\
\text { Russia with Italy or } \\
\text { Russia with France } \\
\text { in Hofstede's } \\
\text { Cultural Dimensions }\end{array}$ \\
\hline $\begin{array}{l}\text { Cultural } \\
\text { Types: the } \\
\text { Lewis Model }\end{array}$ & $\begin{array}{l}\text { Mark Powell's } \\
\text { types of cultures } \\
\text { (Fact cultures - } \\
\text { People cultures - } \\
\text { Trust cultures) } \\
\text { Lewis Model } \\
\text { (in short for } \\
\text { advanced groups) }\end{array}$ & $\begin{array}{l}\text { Lewis Model in } \\
\text { details } \\
\text { (Linear-active, } \\
\text { Multi-active } \\
\text { and Reactive) } \\
\text { Comparison of } \\
\text { Russia with any } \\
\text { country by students' } \\
\text { interests }\end{array}$ & $\begin{array}{l}\text { Lewis Model in } \\
\text { details } \\
\text { (Linear-active, } \\
\text { Multi-active } \\
\text { and Reactive) } \\
\text { Comparison of e.g. } \\
\text { Russia with Italy or } \\
\text { Russia with France }\end{array}$ \\
\hline $\begin{array}{l}\text { Introduction } \\
\text { about Russia }\end{array}$ & $\begin{array}{l}\text { Short profile of } \\
\text { Russia (what we } \\
\text { know about } \\
\text { ourselves) }\end{array}$ & $\begin{array}{l}\text { Profile of Russia } \\
\text { (what we know } \\
\text { about ourselves, how } \\
\text { we evaluate } \\
\text { ourselves) }\end{array}$ & $\begin{array}{l}\text { Comprehensive } \\
\text { insight into Russia. } \\
\text { Comparative } \\
\text { analysis of Russia } \\
\text { with students' native } \\
\text { countries } \\
\text { (history, geography, } \\
\text { art, culture, }\end{array}$ \\
\hline
\end{tabular}




\begin{tabular}{|c|c|c|c|}
\hline & & & $\begin{array}{l}\text { literature, language, } \\
\text { and etc.) }\end{array}$ \\
\hline $\begin{array}{l}\text { Culture } \\
\text { (definition } \\
\text { and depth of } \\
\text { understanding }\end{array}$ & $\begin{array}{l}\text { Culture Iceberg } \\
\text { (basic terms and } \\
\text { the notions } \\
\text { understanding) }\end{array}$ & $\begin{array}{l}\text { Culture Iceberg } \\
\text { (detailed description } \\
\text { and deep } \\
\text { understanding) }\end{array}$ & $\begin{array}{l}\text { Culture Iceberg } \\
\text { (detailed description } \\
\text { and deep } \\
\text { understanding) }\end{array}$ \\
\hline $\begin{array}{l}\text { Level of the } \\
\text { Programme }\end{array}$ & $\begin{array}{l}\text { Bachelor } \\
\text { (Russian } \\
\text { students) }\end{array}$ & $\begin{array}{c}\text { Master } \\
\text { (Russian students) }\end{array}$ & $\begin{array}{c}\text { Master } \\
\text { (Foreign students) } \\
\text { e.g. Italian or French } \\
\text { students } \\
\end{array}$ \\
\hline
\end{tabular}

The most important step in the course of mastering the intercultural communicative competence is its evaluation. The development of an intercultural engagement toolkit for students was our next goal.

We summed up the best practices of the universities engaged in the research and put them in table 2 differentiating them by the types of speech activity.

Table 2. Toolkit to evaluate students' Intercultural Communicative Competence [19].

\begin{tabular}{|c|c|c|c|c|}
\hline \multirow[b]{2}{*}{$\begin{array}{l}\text { Types of } \\
\text { speech } \\
\text { activity }\end{array}$} & \multirow[b]{2}{*}{$\begin{array}{l}\text { Instruments of } \\
\text { assessment }\end{array}$} & \multicolumn{3}{|c|}{ Level of the Programme } \\
\hline & & $\begin{array}{l}\text { Bachelor } \\
\text { (Russian } \\
\text { students) }\end{array}$ & $\begin{array}{c}\text { Master } \\
\text { (Russian } \\
\text { students) }\end{array}$ & $\begin{array}{c}\text { Master } \\
\text { (Foreign } \\
\text { students) }\end{array}$ \\
\hline \multirow{3}{*}{ Writing } & $\begin{array}{l}\mathrm{CV} \text { and } \mathrm{a} \\
\text { Covering letter }\end{array}$ & + & + & no \\
\hline & Business letters & + & no & no \\
\hline & Portfolio & + & + & no \\
\hline Telephoning & $\begin{array}{l}\text { Telephone } \\
\text { etiquette }\end{array}$ & + & no & no \\
\hline \multirow{4}{*}{ Speaking } & Public speaking & + & + & + \\
\hline & Interviewing & + & + & + \\
\hline & Negotiating & + & + & + \\
\hline & $\begin{array}{l}\text { Presentation of a } \\
\text { theme }\end{array}$ & + & + & + \\
\hline \multicolumn{5}{|c|}{ Other instruments } \\
\hline \multirow{2}{*}{ Simulation } & Role-plays & + & + & no \\
\hline & Negotiations & + & + & no \\
\hline \multirow{3}{*}{$\begin{array}{l}\text { Internationa } \\
\text { I Project } \\
\text { Working }\end{array}$} & Virtual Projects & + & + & + \\
\hline & Case Studies & no & + & + \\
\hline & Off-line Projects & no & + & + \\
\hline
\end{tabular}

Some examples of assessment tasks for foreign students are given below.

After studying Tomalin's Country and Personal Cultural Profiles student $R$. in Figure 1 is answering the question "Am I ready to do business with Russia?" in the project. 


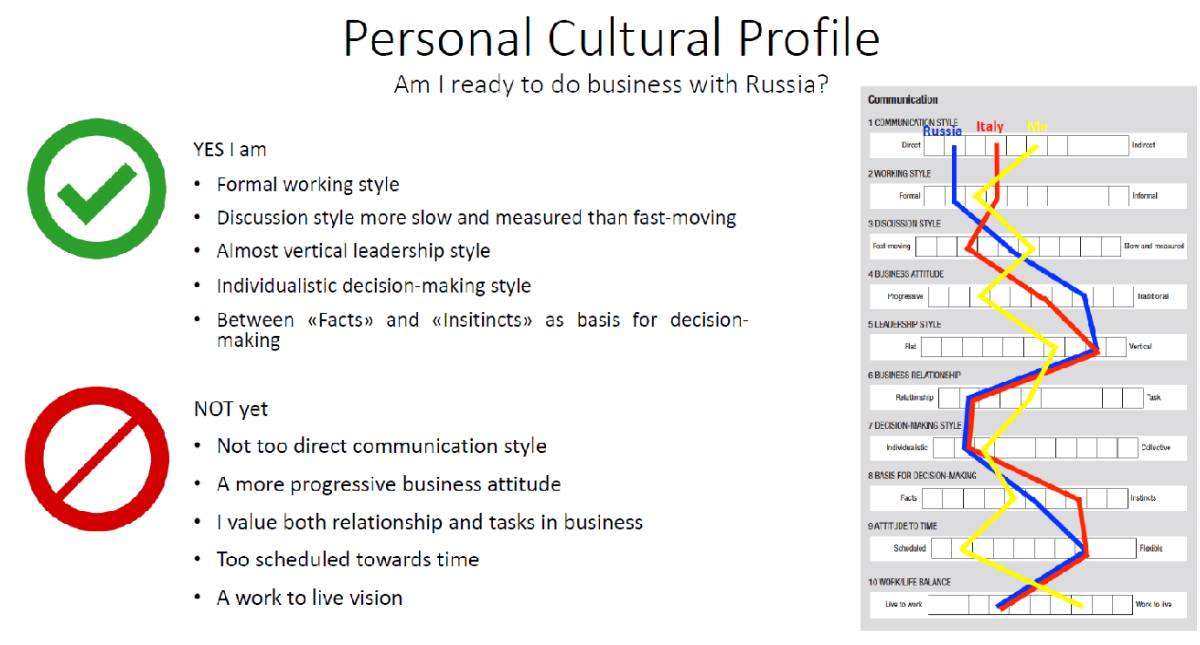

Fig. 1. Am I ready to do business with Russia? (a project fragment).

Another student $M$. in Figure 2 is answering the question "Am I ready to deal with Russians?" in the project.

\section{AM I READY TO DEAL WITH RUSSIAN PEOPLE?}

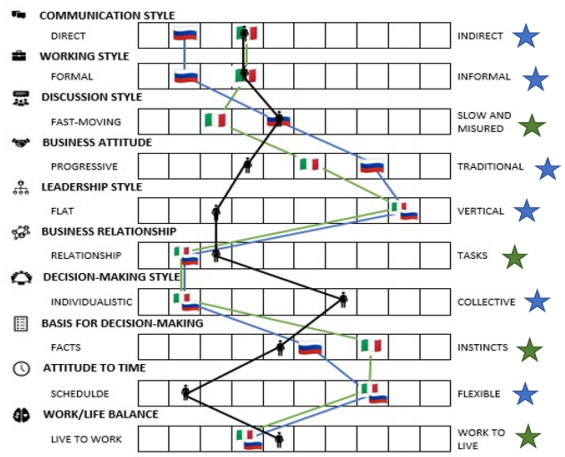

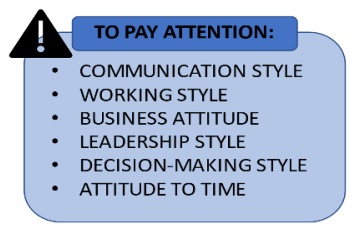

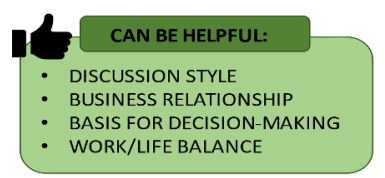

Fig. 2. Am I ready to deal with Russians? (a project fragment).

Some other topics of Projects: "Think Globally - Act Locally", "Virtual Influencers in hospitality internship" to name a few.

\section{Discussion}

The research results indicate that different forms of assessment are suitable for assessing the respective part of the intercultural communicative competence, and multiple forms of assessment should be employed to assess and improve students' intercultural communicative competence.

One more driving instrument in teaching International Communication discipline is referring to the documentary videos of the Gurus like Richard D. Lewis, Geert Hofstede or Barry Tomalin. Just two quotations from them: 
"Culture is the fifth skill" Barry Tomalin [9];

"Culture as Mental Programming or software of the mind", Geert Hofstede [6].

In 2018 Richard D. Lewis was speaking at the conference in St Petersburg, Russia, an event reported as the largest 'humanitarian forum'. The conference theme was 'Contours of the Future in the Context of the World's Cultural Development" [22].

Great idea is to read and discuss his speech (13 pages long article) with Master students to get their deeper understanding of the issues of the future course of humankind in the $21 \mathrm{st}$ century, the driving forces in globalization in order to come to some individual or collective judgments and conclusions on the theme.

\section{Conclusion}

Changes in our unpredictable times inevitably require a great contribution to the complicated process of intercultural communicative competence formation at least in higher education.

A deep understanding of cultures and cross-cultural tolerance of students will help to develop this competence.

Since teachers and trainers play a crucial role in preparing young people to interact in a multicultural world we must keep our finger on the pulse, reacting to the slightest changes in cross-cultural communication on a global scale.

Universities should fully commit to a long-term and evidence-based systems change approach in raising the level of their university's intercultural competence as a whole and embed the development of cross-cultural competence in the curriculum by closely aligning it to the disciplinary content, developing intercultural communicative competent. Higher education institutions seeking to transform their efforts to better educate learners in the $21 \mathrm{st}$ century will make this commitment.

Education needs to inspire people's minds, intercultural communication disciplines should stir their emotions, motivate them and support them to work locally or internationally.

\section{References}

1. A.R. Díaz, et al., Intercult Comm Edu, 4(1), 106-121 (2021). https://doi.org/10.29140/ice.v4n1.449

2. L. Baker, Int J Res Serv-Learn Commun Engag, 7(1), 2 (2019)

3. D.K. Deardorff, Int Educator, 13(3), 13-15 (2004)

4. D.K. Deardorff, J Stud Int Edu, 10(3), 241-266 (2006). https://doi.org/10.1177/1028315306287002

5. S. Douglas, M. Rosvold, Canad J App Ling, 21(1), 23-42 (2018). https://doi.org/10.7202/1050809ar

6. G. Hofstede, G.J. Hofstede, M. Minkov, Intercultural Cooperation and Its Importance for Survival (McGraw-Hill, 2010)

7. R.D. Lewis, When cultures collide: leading across cultures (Nicholas Brealey Publishing, 2006)

8. R.D. Lewis, Train, Lang Cult, 3(3), 8-20 (2019). https://doi.org/10.29366/2019tlc.3.3.1 
9. B. Tomalin, M. Nick, The World's Business Cultures and How to Unlock Them (Thorogood Publishing, 2007)

10. M. Powell, International Negotiations (Cambridge University Press, New York, 2012)

11. K. Eringa, et al., Res Hospit Manag, 5(2), 187-198 (2015). https://doi.org/10.1080/22243534.2015.11828344

12. M. Byram, Teaching and assessing intercultural communicative competence (Multilingual Matters, Clevedon, 1997). http://dx.doi.org/10.14705/rpnet.2016.000411

13. S. Eisenchlas, S. Trevaskes, Intercult Edu, 18(5), 413-425 (2007). https://doi.org/10.1080/14675980701685271

14. R.L. Griffith, et al., Assessing Intercultural Competence in Higher Education: Existing Research and Future Directions. Research Report ETS RR-16-25 (2016). https://doi.org/10.1002/ets2.12112

15. P. Yang, Int Edu Stud, 8(8) (2015). https://doi.org/10.5539/ies.v8n8p67

16. M.A. Kramer, N. Kristen, Building intercultural competence in the language classroom. Faculty Publications: Department of Teaching, Learning and Teacher Education, in S. Dhonau (ed), Unlock The Gateway To Communication, Central States Conference Report, 1-18 (Crown Prints, Eau Clarie, 2014)

17. J. Huber et al., Developing intercultural competence through education (Council of Europe Publishing, 2014)

18. G.G. Hiller, Innovative methods for promoting and assessing intercultural competence in higher education, in Proceedings of Intercultural Competence Conference. August, 2010, 1, 144-168 (2010)

19. T.N. Yefremtseva, Edu. Sci. Edu Person, 3, 108-110 (2011)

20. C.S. Fong, D. Witt, Malaysian J Learn Instr, 16(2), 97-123 (2019)

21. M. Powell, International Negotiations (Cambridge: Cambridge University Press, 2012).

22. The Contours of the Future in the Context of the World's Cultural Development (SPbUHSS, St. Petersburg, 2018) 